\title{
Hogyan alakítják és írják újra az ideológiákat az általuk életre hívott jótékonyság során szerzett tapasztalatok? \\ Zakariás Ildikó: Jótékony nemzet. Szolidaritás és hatalom a kisebbségi magyarok segítésében. Budapest: MTA TK Kisebbségkutató Intézet - Kalligram Kiadó. 2018.
}

DOI: $\underline{10.54742 / \text { tabula.2019.1-2.05 }}$

1.

Zakariás Ildikó könyve azt vizsgálja, hogy milyen társadalmi értelmezések mozgatják a jótékonyságot. Azon belül egy speciális területre, a kisebbségi létben élő magyarság felé irányuló anyaországi segítő tevékenységre fókuszál. Az írás alapgondolata, hogy a támogatás vagy a nem támogatás ideológiák által determinált jelenség, és mint ilyen, folyamatos változás alatt áll. Az értelmezések, tapasztalatok és újraértelmezések nyomán fogalmazódnak meg és jönnek létre a segítési akciók. Az ideológiai háttér alapjaiban szabja meg a segítést, befolyásolja azt, hogy hogyan változik meg a segítők és segítettek köre, valamint a segítés módja (Zakariás 2018:252). A szerző a szomszédos országokban kisebbségi létben élő magyarokat segítő jótékony, filantróp tevékenységek vizsgálatán keresztül arra a következtetésre jut, hogy a magyarországi segítő szándékban a nemzeti azonosság olyannyira központi szerepet kap, hogy az leggyakrabban a cselekvéseket motiváló, kiváltó okként azonosítható. Zakariás Ildikó szerint ebben a viszonyrendszerben a segítés két meghatározója a hátrány és az elmaradottság. A segítők többsége szerint, a határon túli magyarok egyrészt hátrányban vannak, mert kultúrájukat, hagyományaikat, nemzeti identitásukat fenyegető közegben élik mindennapjaikat. Másrészt, alapvetően elmaradottabb gazdasági környezet veszi őket körül. Hozzájuk képest nyugatinak, fejlettebbnek, tehetősebbnek minősül a magyar társadalom, ezért az anyaország polgáraitól és hatalmi elitjétől elvárható, hogy segítse a rosszabb körülmények között élő nemzettársait. (Zakariás 2018:14)

2.

A könyv logikusan szerkesztett, a következetesen egymásra épülő részek fokozatosan vezetik be az olvasót az írás által feltárt jelenség problémavilágába. A segítés kérdéskörét egy hármas struktúra mentén járja körül a szerző. Egyrészt arra kíváncsi, hogy a segítők és a segítettek nézetei hogyan formálódnak a segítés folyamata során. Másrészt megvizsgálja, hogy a támogatást hogyan árnyalják a nemzetről, a magyarságról szóló képzetek. Harmadrészt rákérdez, hogy a segítségnyújtás hatalmi aspektusai hogyan írhatók le és miként értelmezhetők ebben a segítési folyamatban.

A bevezető fejezetet az elméleti áttekintés követi. Ebben egyrészt végigvezeti azokat a kutatási eredményeket, amelyek a segítők motivációira fókuszálnak, majd áttekinti a szolidaritáshoz kapcsolódó nemzeti ideológiák téziseit és értelmezi az érdemesség narratíváit a jótékony akciókban. Másrészt, a segítő-segített pozíciók aszimmetriája címü fejezetben fölvázolja, hogy milyen elméleti modellek foglalkoznak a filantróp segítés hatalmi kérdéseivel. A könyv következő fejezete tágabb 
perspektívából mutat rá a segítés címzettjeit, azaz a kisebbségi magyarokat támogató tevékenységek ideológiai hátterére. A segítő-segített viszony feltárását interjúk készítésével és jótékony tevékenységek résztvevő megfigyelésével végezte a szerző. Az alábbi négy kiválasztott filantróp program dokumentálásán és elemzésén keresztül válaszol a vizsgálat fő kérdéseire. A kutatás tárgyát képezi egy budaörsi testvériskola projekt, amelyben a segítés címzettjei kárpátaljai magyarok voltak. Talán a legsokrétúbb az a gimnáziumi magyar nyelvápolási program volt Budapesten, amely Kárpátaljára, Erdélybe, Vajdaságba és Felvidékre irányult. A vizsgálat kiterjed egy szentendrei iskola összetett, kárpátaljaiakat segítő programjára, valamint egy olyan projektre, amelyben a magyarul tanuló csángók kvázi keresztszüleivé váltak a segítő magyarországi - vagy erdélyi - önkéntesek. Zakariás Ildikó a konkrét tereptapasztalatok nyomán azt vizsgálja, hogy a segítés során hogyan jelennek meg a nemzeti azonosság és különbözőség ideológiái. Valamint hatalmi kérdésként veszi górcső alá a segítést, bemutatva a segítő és segített aszimmetrikus viszonyát a segítettek nézőpontjából. A jótékonyság intim aspektusaira is kitér, amikor a támogatók és a támogatottak között kialakuló személyes kapcsolatokat mutatja be.

4.

A szerző értelmezése abból az alaptézisből indul ki, hogy a segítés ideológiák által meghatározott tevékenység, és ezen ideológiák döntően a segítési folyamat során változnak. A találkozás pillanataiban válik tetté a korábbi elképzelés, ekkor derül ki, hogy azonos jelentéseket társítanak-e az egyes felek a cselekvésekhez, és az elgondolt ideológiákhoz vagy sem. Ha igen, megtörténhet az ideológiák megerősítése (Zakariás 2018:170), ha nem, akkor viszont mód nyílik a képzetek transzformálására, módosításra, vagy akár a cselekvés meghiúsulására is.

Az írás bepillantást nyújt abba a folyamatba, amelyben a legkülönbözőbb segítői attitűdök (nemzeti szolidaritás; gyermekek segítése; elmaradottság enyhítése; keresztény karitasz) az alkalmazás során változnak, újra értelmeződnek, új motivációk kapcsolódnak hozzájuk. „Így adhat kapaszkodót a nemzeti azonosság, a magyarság megmaradásának eszméje a szegénységtől megrettenő jótékonykodónak, és jelent mankót a hátrányos helyzetű gyerekek segítésének eszméje a nyelvváltó vagy a nemzeti megmaradás diskurzusait visszautasító közösségekben.” (Zakariás 2018:254.) A vizsgált önkéntesek esetében a nemzeti ideológia a fő értelmezési keret, amelyben megvalósul a segítés. Ha valamilyen okból a nemzeti szolidaritás mentén nem alakítható ki a jótékony tevékenység, akkor másodlagos opcióként bukkan fel az általánosabban vett hátrányos helyzet orvoslása, a keresztényi filantróp eszme, vagy a gyermekek segítésének értelmezési kerete. A könyv lényegében a jótékonyság indoklásaként és legitimálásaként használt különböző ideológiák játékát mutatja meg az olvasó számára. Azt a sérülékeny, a résztvevők és sokszor a kutatók számára is láthatatlanul, kibeszéletlenül hagyott mezsgyét, amely meghatározza, hogy voltaképpen miért segít a segító és szerinte miért szorul erre a rászoruló. Erre a legelemibb kérdésre kínál multivokális választ az írás.

Zakariás Ildikó monográfiája olyan értékes szempontokat emel be a jótékonyság múködésmechanizmusairól szóló diskurzusba, amelyek a filantrópia-kutatásokból gyakran kimaradnak. Ilyen például az, hogy számol a társadalmi, gazdasági és politikai kontextussal, amelyben megvalósul a jótékonyság (Zakariás 2018:51). Ugyanakkor az önkéntes cselekvések ideológiai meghatározottságának hangsúlyozása, vagy a segítő-segített pozíciók egymásra reflektáló, a jótékonysági folyamatot kölcsönösen formáló viszonyának értelmezése szintén meghatározó eredmények. 
Továbbá megállapítja, hogy a vizsgált jótékonysági formák a nemzeti ideológiák megnyilvánulásának terepei, ahol a segítók megélhetik a magyarságról, nemzeti azonosságról elgondolt elképzeléseiket. A segítési akciókat vezérlő magasztos szándék, a szenvedés vagy a hiány csökkentése kiegészül a segítő saját individuális szempontjaival, önmegvalósító szándékaival, amelyben a nemzeti ideológiák megtapasztalásának vágya válik fontossá.

A könyv megmutatja, hogy a segítők hogyan jelölik ki a segítés alanyait, vagyis hogyan megy végbe a segítésre érdemesség meghatározása. Ez az aspektus gyakran rejtve marad, miközben rendkívül fontos, mert nem csak a segítők motivációit árnyalja, hanem azt a folyamatot is felfedi, ahogyan a jótékonyság révén a segítők meghatározzák a rászorultság tényét. Ebből következően a jótékonyság során megvalósuló kiválasztási folyamat megmutatja azokat az önkéntesek által preferált problémaköröket, amelyek megalkotják a segítés szükségletét. Ezzel tulajdonképpen már a segítési folyamat kezdetén egy aszimmetrikus viszony jön létre, amely imlicit vagy explicit módon végigkíséri a segítés folyamatát. A szerző Axel Honneth elismerés elméletére alapozva mélyebbre ás, és olyan új jelentésrétegeket tár fel, amelyek döntően mozgatják a segítés cselekvésének szálait. Az elismerés és a szolidaritás megteremtésének mozzanatai kapcsán vizsgálja azt is, hogy hogyan jelenik meg és hogyan érvényesül a segítés címzettjeinek nézőpontja. Ugyanakkor fontos hangsúlyozni, hogy Zakariás az adományozás gesztusában nem egyszerüen a támogatók hatalmának megerősítését és fenntartását látja, hanem az érdemesség kérdését is bevonja az elemzésbe. Így megközelítve egy közösségre irányuló adományozás lényegében elismerő gesztusokat is tartalmaz, és a honnethi értelemben a szolidaritás mint elismerési forma megnyilvánulásának a helye lesz (Zakariás 2018:78).

8.

Az egyik legfontosabb eredménye a könyvnek, hogy megmutatja azt az összetett és kölcsönös egymásra reagáló viszonyt, amelyben a segítés létrejön. A segítő és a segített egyaránt alakítja, építi, befolyásolja a segítés folyamatát. A kölcsönösség iránti igény nyilvánul meg a segítés viszonzásának szándékában is. „A támogatótámogatott találkozások, amennyiben ez utóbbiak otthonában jönnek létre, általában együtt járnak a támogató megvendégelésének vagy elszállásolásának gesztusaival, gyakorlataival. Azokban az értelmezési helyzetekben, amikor a jótékonykodás és maga a találkozás a támogatott számára beváltja a »segítés « ígéretét, magyarán azt a támogatott hasznosként, segítségként, céljaival egybevágóként értékeli, a vendéglátás viszontjándékként, a támogató szimbolikus elismerésének, a hálának a kifejezéseként múködik.” (Zakariás 2018:203.)

Zakariás Ildikó monográfiája felhívja a figyelmet arra, hogy a segítési folyamat egy bináris viszony, amelyben lehetőség nyílik a benne részt vevők előzetes, szolidaritással kapcsolatos elképzeléseinek reflexiójára. Ahogy az írásból kiderül, a vizsgált önkéntesek több esetben reflektálnak a segítési gyakorlatokra és megfogalmazzák kritikáikat a nemzeti szolidaritás müködésével kapcsolatban. A szerző felteszi a kérdést, hogy vajon a jótékonyság kapcsán, a segítés mikrovilágában megszülető kritika képes-e szélesebb körbe eljutni, általánossá válni és az önkéntesség gyakorlatait, esetleg a támogatáspolitika struktúráit újra írni? Mindenképpen izgalmas lenne ezt a felvetést a továbbiakban megvizsgálni. 10 .

A könyv a jótékonyság - mint társadalmi konstrukció - kritikai elemzését adja. A kutatási probléma megközelítésének módja, a feltett kutatási kérdések, a vizsgálat 
módszerei és maga az elkészült írás mind a szerző alapos szakmai munkáját dicsérik. A monográfia érvényes szemléletbeli iránymutatást jelenthet és hasznosítható kutatási eredményeket adhat az önkéntesség, jótékonyság témakörét vizsgálók számára. Ugyanakkor szélesebb körben szolgálhat értékes eredményekkel a társadalmi részvételi formákkal, a szolidaritás megnyilvánulásaival, a jótékony cselekvések politikai aspektusaival és a nemzeti ideológiák kérdésével foglalkozó kutatók számára. Kifejezetten izgalmas perspektívát nyújthat a könyv a segítési folyamatot egy irányból - legtöbbször a segítők perspektívájából - feltáró kutatóknak. 